\author{
AMERICAN JOURNAL OF FOOD AND NUTRITION \\ Print: ISSN 2157-0167, Online: ISSN 2157-1317, doi:10.5251/ajfn.2011.1.3.102.108 \\ (C) 2011, ScienceHuß, http://www.scihub.org/AJFN
}

\title{
Heavy metal concentrations in periwinkle (Litorina $L$ ittorea) and tilapia (Tilapia Zilli) from the coastal water of Warri, Nigeria.
}

\author{
Olowoyo, D. N \\ Department of Industrial Safety and Environmental Technology, Petroleum Training Institute, \\ Effurun-Warri, Delta state
}

\begin{abstract}
Heavy metal (HM) contents in periwinkle and tilapia from Warri coastal water were carried out during dry and wet seasons of 2008 and 2009. Samples were collected from ten sampling locations. HM was determined using atomic absorption spectrophotometer-varian model spectral AA 220. The range of $\mathrm{HM}$ concentrations viz $\mathrm{Pb}, \mathrm{Ni}, \mathrm{Fe}, \mathrm{Cu}, \mathrm{Zn}, \mathrm{Cd}, \mathrm{Mn}$ and $\mathrm{Cr}$ in periwinkle were found to be $0.68-10.34 \mathrm{mg} / \mathrm{kg}, 1.21-8.01 \mathrm{mg} / \mathrm{kg}, 198.73-457.11 \mathrm{mg} / \mathrm{kg}, 0.002-4.60 \mathrm{mg} / \mathrm{kg}$, $1.02-5.06 \mathrm{mg} / \mathrm{kg}, 0.002-0.54 \mathrm{mg} / \mathrm{kg}, 10.00-72.27 \mathrm{mg} / \mathrm{kg}$ and $205.09-1,453 \mathrm{mg} / \mathrm{kg}$ respectively. In tilapia, the concentrations ranged from $0.73-3.25 \mathrm{mg} / \mathrm{kg}, 0.72-482.00 \mathrm{mg} / \mathrm{kg}, 0.001-1.93 \mathrm{mg} / \mathrm{kg}$, $3.02-459.00 \mathrm{mg} / \mathrm{kg}, \quad 0.83-3.75 \mathrm{mg} / \mathrm{kg}, 0.65-1.45 \mathrm{mg} / \mathrm{kg}, 1.25-5.01 \mathrm{mg} / \mathrm{kg}$ and $344.02-969.00 \mathrm{mg} / \mathrm{kg}$ respectively. The results show that $\mathrm{Fe}, \mathrm{Mn}$ and $\mathrm{Cr}$ in periwinkle and only $\mathrm{Cr}$ in tilapia were higher than other metals determined. The concentrations of heavy metals during wet season were slightly higher than dry season except in few occasions. Also, the heavy metal concentrations of the year 2009 were generally higher than the year 2008 indicating more of these metals were discharged or introduced into water/sediment environment than the previous year which enhanced bio-accumulation in these fauna. These generally suggest an evidence of these fauna to bio-concentrate these metals.
\end{abstract}

Keywords: Heavy metals, fauna, coastal water, dry and wet seasons, bio-accumulation.

\section{INTRODUCTION}

Heavy metals are natural components of the earth's crust and they can enter the water and food cycles through a variety of chemical and geochemical processes (NDES,1999; Gbaruko and Friday, 2007). The fate of heavy metals introduced by human activities into aquatic ecosystem have recently become the subject of wide spread concern, since beyond the tolerable limits they become toxic (Pocock et al.,1994; koller et al., 2004).The World Health Organisation as well as a United Nations state that are monitoring eight elements in fish- $\mathrm{Hg}, \mathrm{Cd}$, $\mathrm{Pb}, \mathrm{As}, \mathrm{Cu}, \mathrm{Zn}, \mathrm{Fe}, \mathrm{Sn}$-is obligatory and monitoring of others is suggested (WHO,1971; Staniskiene et al., 2006). Hence, the determination of harmful and toxic substances in water, sediment and biota gives direct information on the significance of pollution in the aquatic environment (Hugget et al.,1973; Gbaruko and Friday, 2007). Also, studies on the pollution status of some fauna in some parts of Nigeria and around Niger Delta area have been reported (Chindah and Braide, 2003; Davies et al, 2006). It is therefore necessary to determine the concentrations of $\mathrm{Pb}, \mathrm{Ni}, \mathrm{Fe}, \mathrm{Cu}, \mathrm{Zn}, \mathrm{Cd}, \mathrm{Mn}$ and $\mathrm{Cr}$ in periwinkle (Litorina littorea) and Tilapia (Tilapia zilli) in Warri coastal area of Delta state, Nigeria. This area is in Niger Delta zone and most essentially one of the popular coastal areas of Nigeria where massive oil exploitation, exploration, production and refining processes are taken place.

\section{MATERIAL AND METHODS}

Sampling: Samples of periwinkle (Litorina littorea) and tilapia (Tilapia zilli) used for the analysis were bought from fishermen fishing along the coast in ten (10) different locations in Fig.1. The samples were thoroughly washed with the sea water, placed in labelled cellophane bags and preserved in ice cooled box. The samples were later transported to the laboratory and stored in the freezer at $-4^{0} \mathrm{c}$ prior to laboratory analysis. Sampling was carried out during dry (march) and wet (august) seasons for year 2008 and 2009 respectively.

Sample preparation: The fleshy parts of Periwinkles were obtained by cracking the shells. The mean soft body and weight for periwinkle and Tilapia samples were determined after drying at $80^{\circ} \mathrm{C}$ for 24 hours (Leung and Furnes, 1999). Heavy metals ( Pb, Ni, 
$\mathrm{Fe}, \mathrm{Cu}, \mathrm{Zn}, \mathrm{Cd}, \mathrm{Mn}$ and $\mathrm{Cr}$ ) were determined from $2.0 \mathrm{~g}$ of finely ground tissue samples homogenized with $25 \mathrm{ml}$ of de-ionized water after $10 \mathrm{ml}$ of concentrated $\mathrm{HCl}$ and $2 \mathrm{ml}$ of $\mathrm{HNO}_{3}$ in succession. The mixture was boiled off to near dryness. Metal concentrations were analysed using flame atomic absorption spectrometer (Varian, AA 220). The results obtained from this analysis were the average of duplicate determinations.

\section{RESULTS AND DISCUSSION}

The Figs. 2, 3, 4 and 5 are HM concentrations in periwinkle for wet and dry seasons of the two years studied while figs. 6, 7, 8 and 9 are for concentrations of heavy metals in tilapia for the same seasons and years investigated.

HM concentrations determined in periwinkle and tilapia varied from one location to another location, from one season to another season and from one year to another year. In general the range of heavy metal concentrations for two consecutive years in periwinkle were found to be $0.68-10.34 \mathrm{mg} / \mathrm{kg}, 1.21$ - $8.01 \mathrm{mg} / \mathrm{kg}, 198.73$ - $457.11 \mathrm{mg} / \mathrm{kg}, 0.02$ $4.60 \mathrm{mg} / \mathrm{kg}, 1.02-5.06 \mathrm{mg} / \mathrm{kg}, 0.002-0.54 \mathrm{mgg} / \mathrm{kg}$, $10.00-72.27 \mathrm{mg} / \mathrm{kg}$ and $205.09-1453 \mathrm{mg} / \mathrm{kg}$ for $\mathrm{Pb}$, $\mathrm{Ni}, \mathrm{Fe}, \mathrm{Cu}, \mathrm{Zn}, \mathrm{Cd}, \mathrm{Mn}$ and $\mathrm{Cr}$ respectively . In the same trend, however, the concentrations of heavy metals in tilapia ranged from $0.73-3.25 \mathrm{mg} / \mathrm{kg}, 0.72$ $482 \mathrm{mg} / \mathrm{kg}, 0.001-1.193 \mathrm{mg} / \mathrm{kg}, 3.02-459.00 \mathrm{mg} / \mathrm{kg}$, $0.83-3.75 \mathrm{mg} / \mathrm{kg}, \quad 3.02 \quad-459.00 \mathrm{mg} / \mathrm{kg}, \quad 0.83 \quad-$ $3.75 \mathrm{mg} / \mathrm{kg}, 0.65-1.45 \mathrm{mg} / \mathrm{kg}, 1.25-5.01 \mathrm{mg} / \mathrm{kg}$ and 344.02 - 969.00mg/kg for Pb, Ni, Fe, Cu, Zn, Cd, Mn and $\mathrm{Cr}$ respectively.

Heavy metal concentrations of $\mathrm{Cr}$, Fe and $\mathrm{Mn}$ were higher in periwinkle than tilapia, even though, both of them bio-concentrate $\mathrm{Cr}$ significantly more than any other metals determined as contained in figs. $2,3,4,5,6,7,8$ and 9. The concentrations of $\mathrm{Cd}$ and $\mathrm{Cu}$ were the least in periwinkle while $\mathrm{Cd}$ and Fe were the least in tilapia. The order of decreasing in concentration of the metals is $\mathrm{Cr}>\mathrm{Fe}>\mathrm{Mn}>\mathrm{Pb}>\mathrm{Ni}>\mathrm{Zn}>\mathrm{Cu}>\mathrm{Cd}$ and $\mathrm{Cr}>\mathrm{Cu}>\mathrm{Mn}>\mathrm{Ni}>\mathrm{Zn}>\mathrm{Pb}>\mathrm{Cd}>\mathrm{Fe}$ for periwinkle and tilapia respectively. More also, the analysis of variance revealed that there is a significant difference at $(p<0.05)$ level of significance for all the metals most especially $\mathrm{Cr}, \mathrm{Fe}$ and $\mathrm{Mn}$ in the analysed periwinkle sample and $\mathrm{Cr}$ in case of tilapia sample.

In general, the bio-concentration of $\mathrm{Cr}$, $\mathrm{Fe}$ and $\mathrm{Mn}$ in periwinkle that was more than tilapia may be due to the fact that periwinkle resides permanently in bottom sediment while tilapia swims in water and partially feeds on sediment.

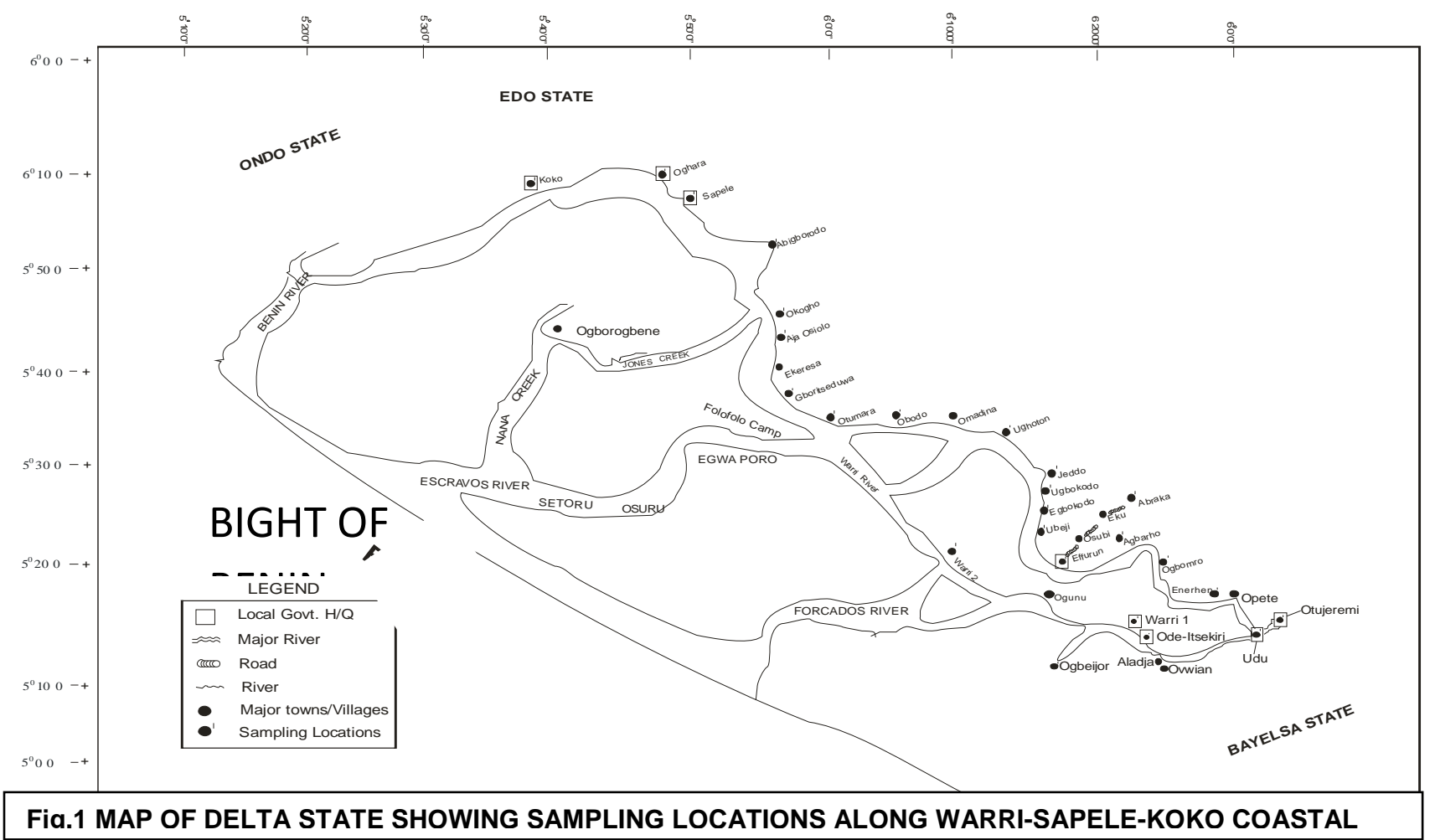


Am. J. Food. Nutr, 2011, 1(3): 102-108

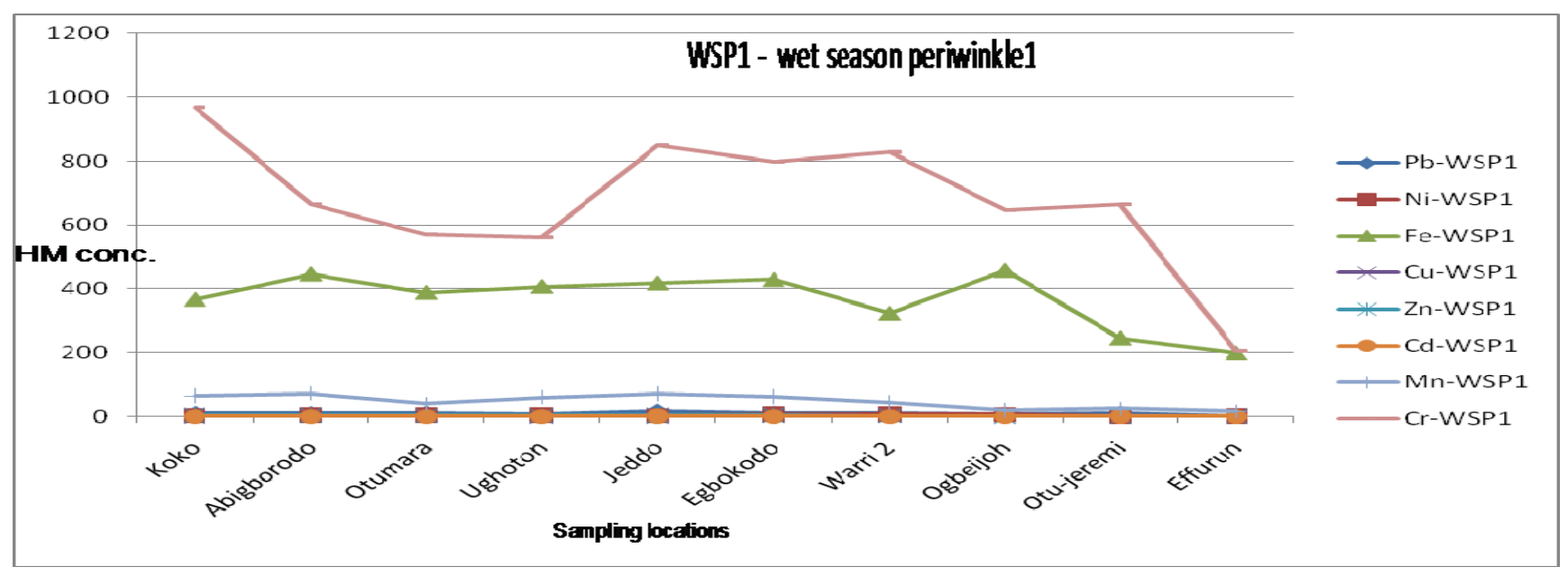

Fig 2: HEAVY METAL CONCENTRATION (mg/kg) IN PERIWINKLE (Litorina littorea) DURING WET SEASON 2008

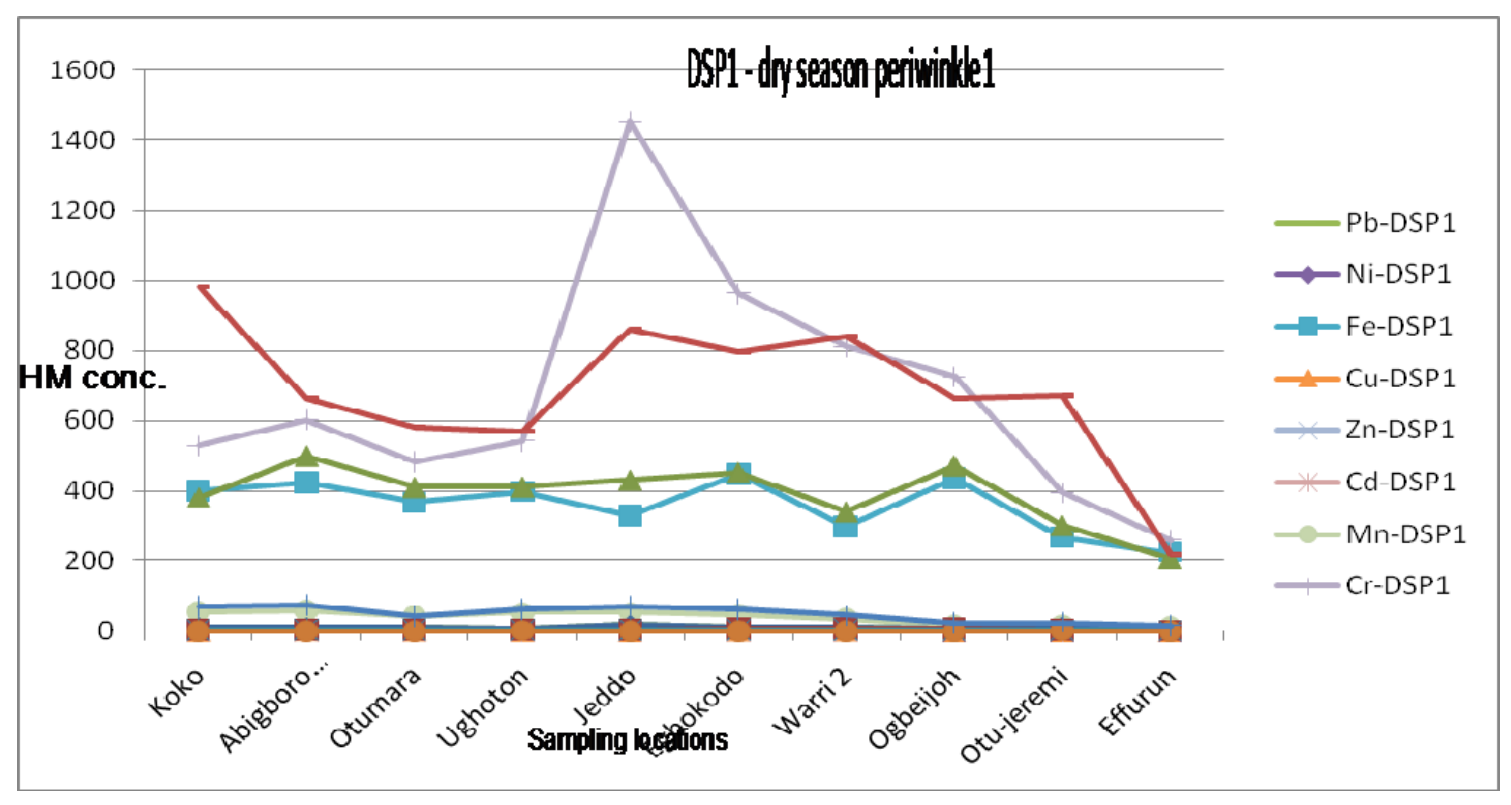

Fig 3: HEAVY METAL CONCENTRATION (mg/kg) IN PERIWINKLE (Litorina littorea) DURING DRY SEASON 2008 
Am. J. Food. Nutr, 2011, 1(3): 102-108

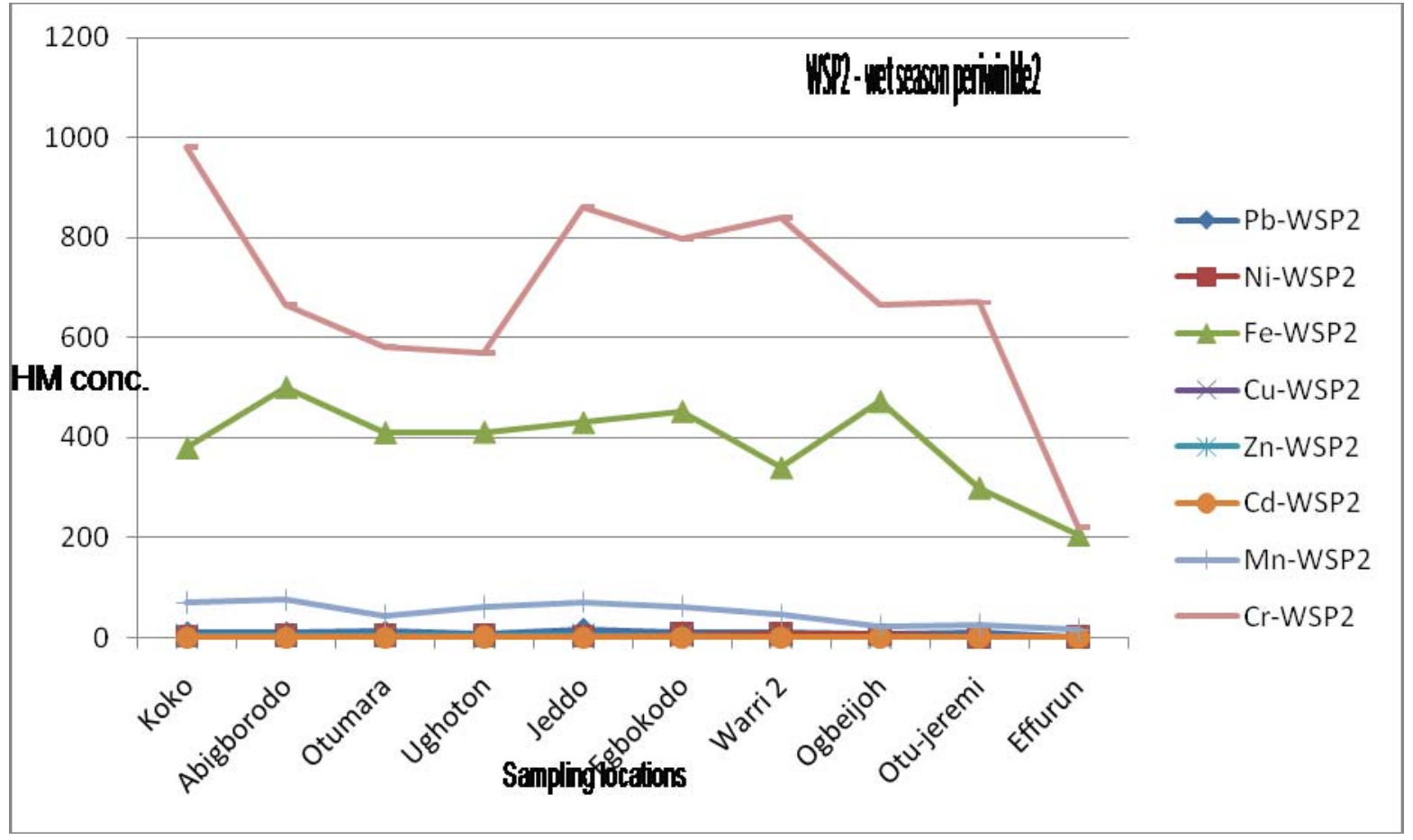

Fig 4: HEAVY METAL CONCENTRATION (mg/kg) IN PERIWINKLE (Litorina littorea) DURING WET SEASON 2009

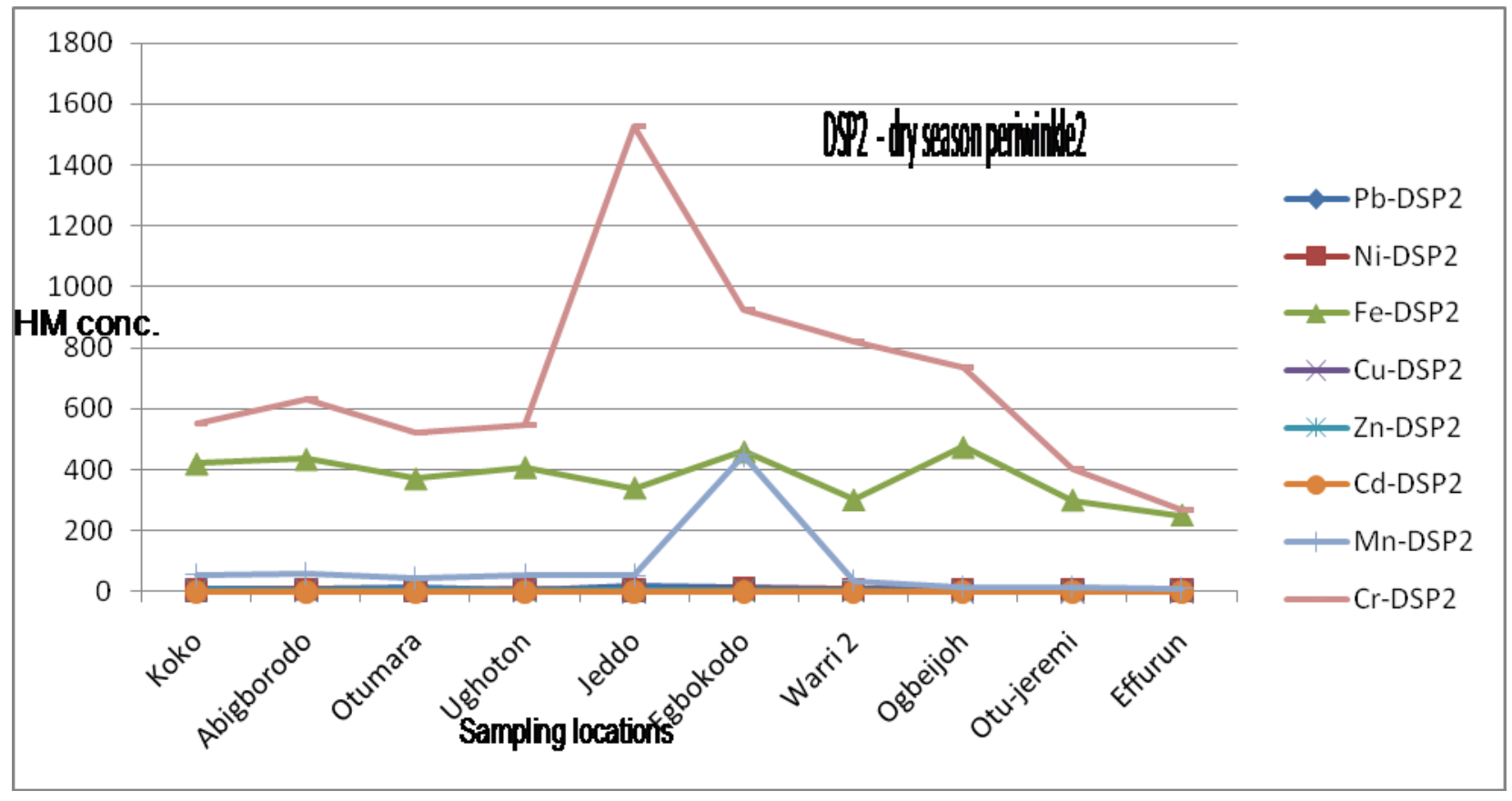

Fig 5: HEAVY METAL CONCENTRATION (mg/kg) IN PERIWINKLE (Litorina littorea) DURING DRY SEASON 2009 


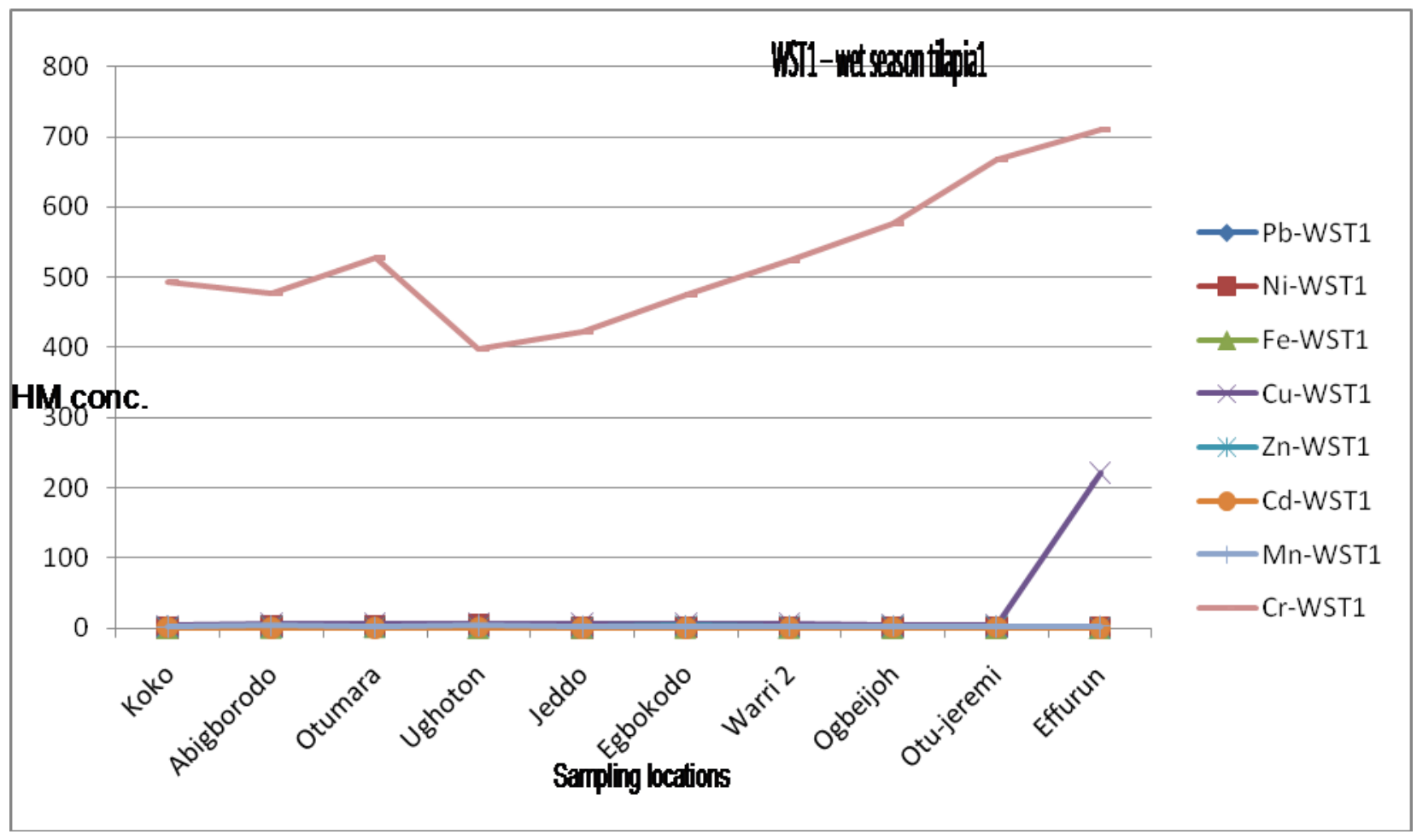

Fig 6: HEAVY METAL CONCENTRATION (mg/kg) IN TILAPIA (Tilapia zilli) DURING WET SEASON 2008.

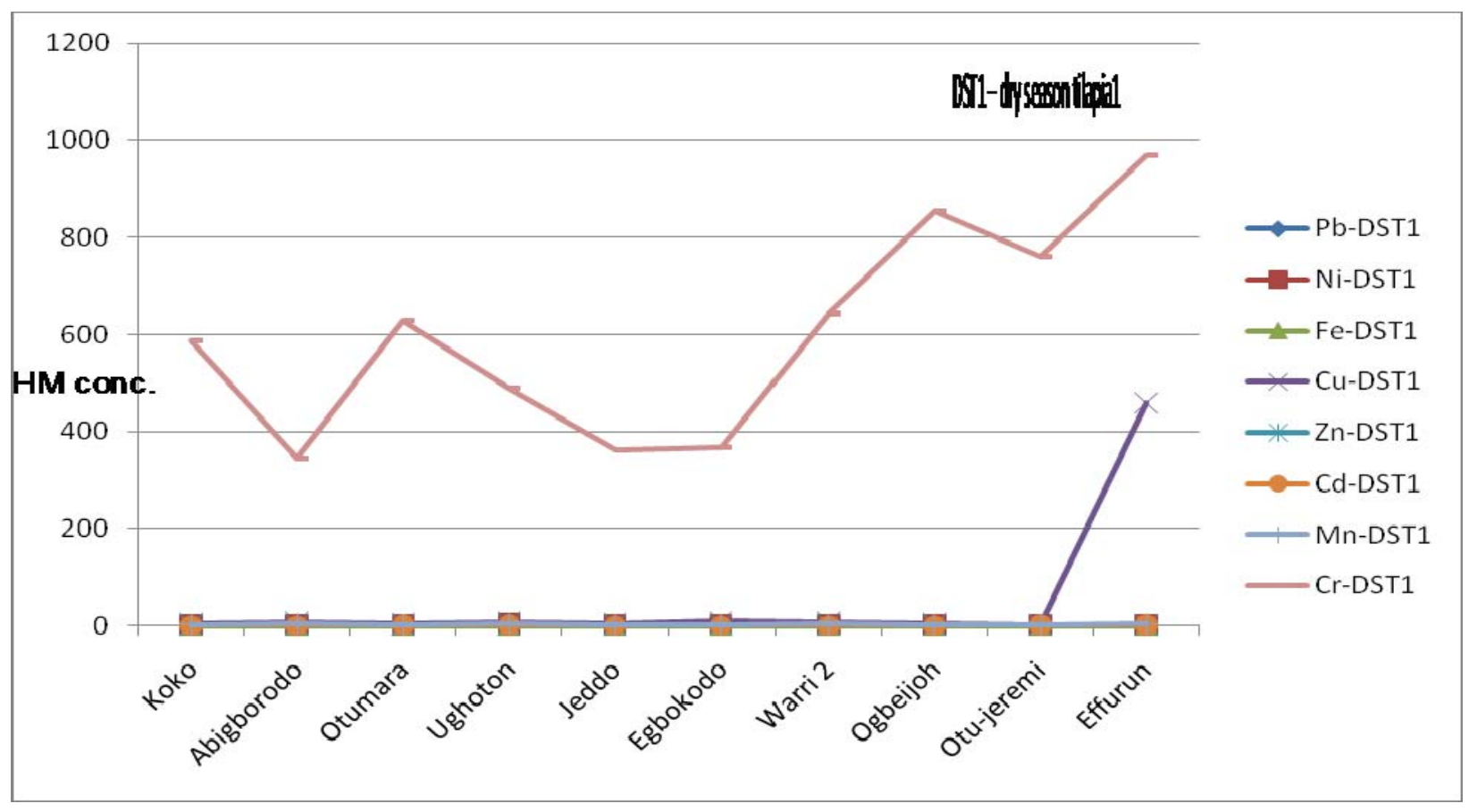

Fig 7: HEAVY METAL CONCENTRATION (mg/kg) IN TILAPIA (Tilapia zilli) DURING DRY SEASON 2008. 
Am. J. Food. Nutr, 2011, 1(3): 102-108

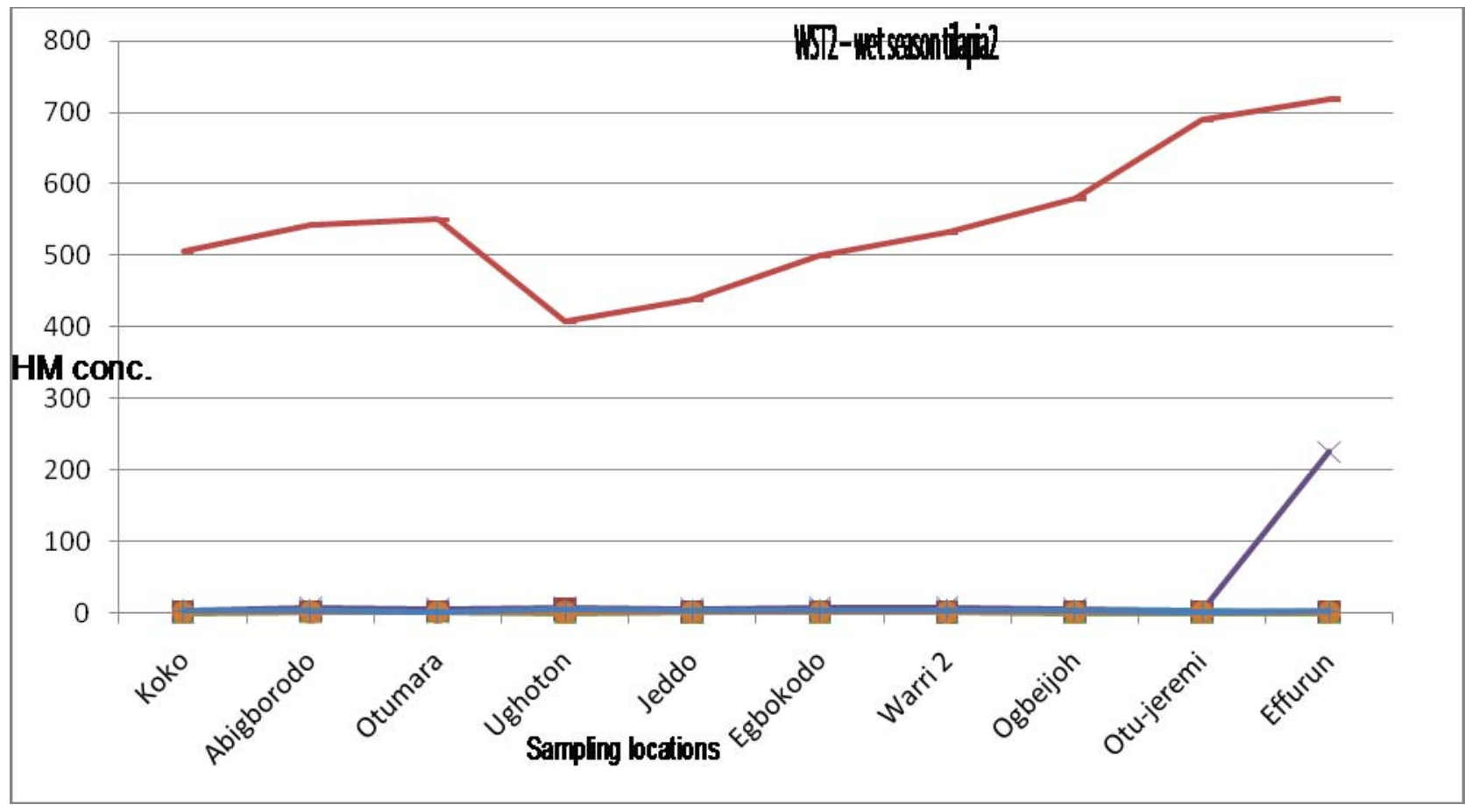

Fig 8: HEAVY METAL CONCENTRATION (mg/kg) IN TILAPIA (Tilapia zilli) DURING WET SEASON 2009.

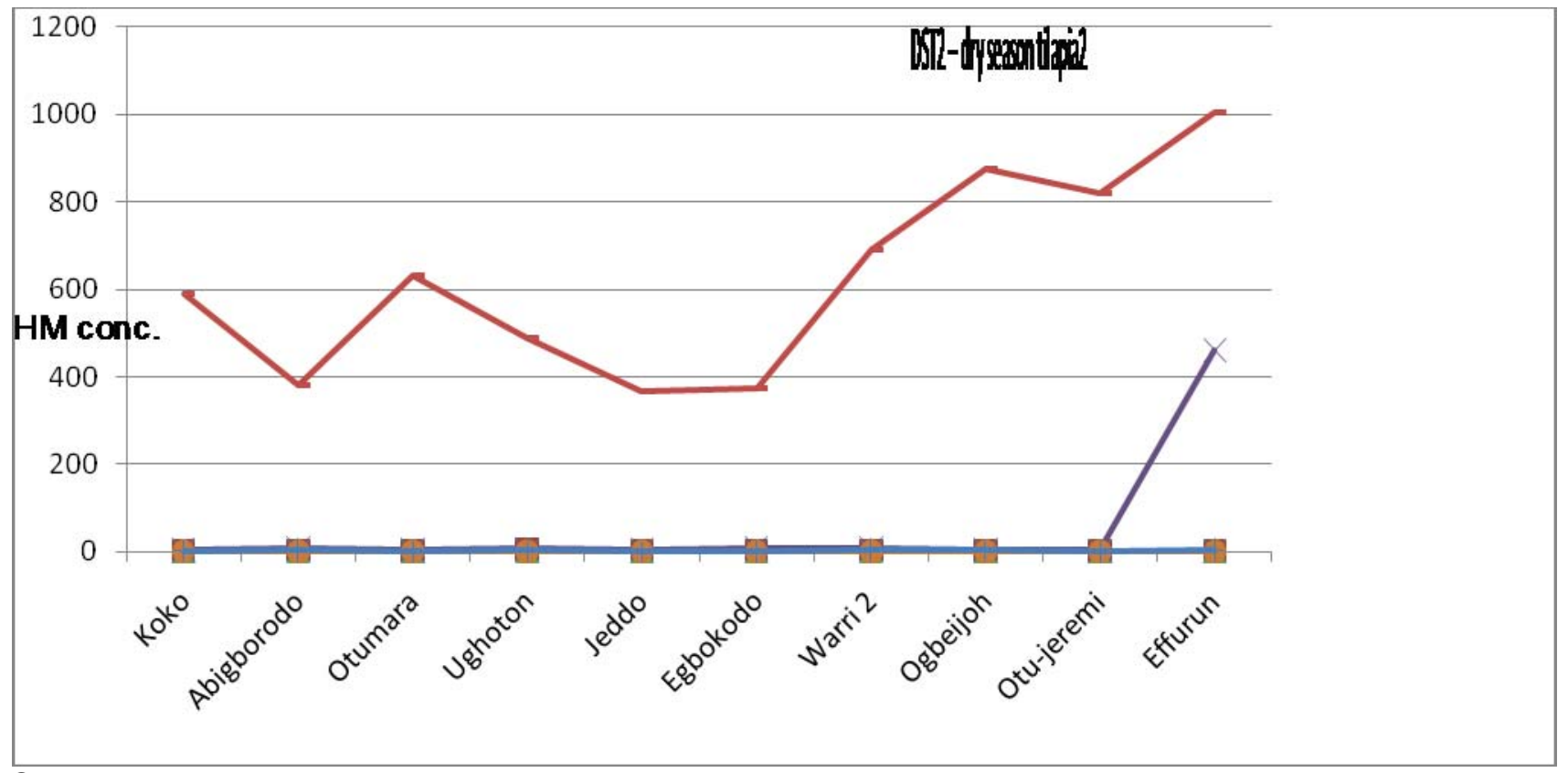

Sampling locations

Fig 9: HEAVY METAL CONCENTRATION (mg/kg) IN TILAPIA (Tilapia zilli) DURING DRY SEASON 2009. 


\section{CONCLUSION}

The high concentrations of $\mathrm{Cr}, \mathrm{Fe}$ and $\mathrm{Mn}$ may be due to industrial and other processing activities such as oil production and refining which can introduce these metals into the water body and eventually sediment from where fauna feed. The two fauna ( periwinkle and tilapia) bio-concentrate all the metals determined because HM concentrations of 2009 was slightly higher than 2008. However, the bioconcentration of periwinkle was significantly higher than tilapia.

\section{ACKNOWLEDGEMENT}

The author warmly appreciates Tudaka Environmental Consultants, Effurun-Warri, Delta state for using their laboratory and equipment

\section{REFERENCES}

Chindah, A.C, Braide, S.A (2003).Cadmium and Lead concentrations in fish species of a brackish wetland/upper bonny Estuary. Niger Delta. J. Nig. Environ. Soc, 1:399 - 405

Davies O.A, Allison, W.E and Uyi, H.S (2006). Bioaccumulation of heavy metal in water, sediment and periwinkle from elechi creek, Niger Delta, Nig. Afri. J. Biotechnol. 5:968 -973
Gbaruko, B.C, Friday O.U (2007). Bioaccumulation of heavy metals in some fauna and flora. Int. J. Environ. Sci. Tech., 4(2):197 - 202.

Hugget, R.J., Bencher, M.E and Slone, H.D (1973). Utilizing metal concentration relationships in the eastern oyster (craostrae Virginica) to detect heavy metal pollution. Wat. Res., 7, $151-540$

Koller, K. , Brown T. , Spurgeon, A. , and Levy, L. (2004). Recent development in low level exposure and intellectual impairment in children. Environ. Health perspect. ,112 (9), 987 -994

Leung, K.M.Y, furness R.W, (1999). Effects of animal size on concentrations of metallothionein and metals in periwinkle (Lithorina Lithorea) collected from fifth of clyde, Scotland, Marine pollut. Bull., 39:126 -136.

Niger Delta Environmental Survey (NDES), (1999). Phase 1 Report, Vol 1.Environmental and Socio -economic characteristics (revised edition).

Pocock, S.J. , Smith, M and Baghurst, P. (1994). Environmental lead and children's intelligence. A systematic review of the epidemiological evidence. Br. Med. J., 304, 1187 - 1197.

Staniskiene, B; Matusevicius, P; Budreckiene, R and Skibniewska, K.A .(2006). Distribution of heavy metals in tissues of freshwater fish in Lithuania. Polish J. of Environ. Stud Vol. 15, 4(585 - 591).

WHO (1971). World Health Organization guideline for water quality, Geneva, first edition, vol.1. 